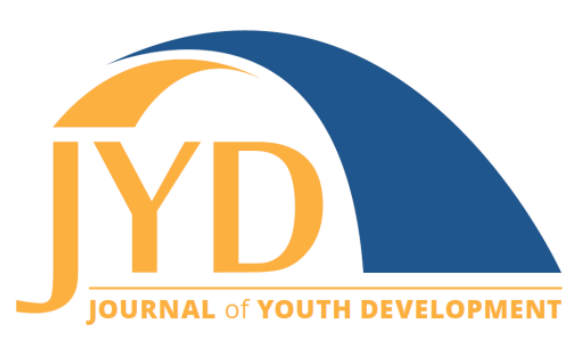

http://jyd.pitt.edu/ | Vol. 16 Issue 5 DOI 10.5195/jyd.2021.1083 | ISSN 2325-4017 (online)

\title{
Cultivating Youth Affinity for College Within the Context of Campus-Based Summer Camps
}

\author{
Barry A. Garst \\ Department of Parks, Recreation and Tourism Management; Clemson University \\ bgarst@clemson.edu
}

Ryan J. Gagnon

Clemson University

rjgagno@clemson.edu

\section{Thomas Clanton}

Young Harris College

tclanton@yhc.edu

\section{Jay Woodward}

Texas A\&M University

drjay@tamu.edu

\begin{abstract}
College and university-based (CUB) summer camps are a prominent pre-collegiate experience targeting middle and high school adolescents, which research suggests may enhance college aspirations and preparedness, develop academic knowledge and skills, and influence future career choices. This study examines factors that predict the relation between affinity for college, program engagement and support, college major selection, and social-emotional outcomes stemming from youth involvement in a CUB camp based on data collected from 641 middle and high school-aged youth who completed an online questionnaire on the last day of the CUB camp. The findings validated a 4-factor model comprised of college brand awareness, college relational expectations, college academic interestscience, and college academic interest-technology. Further, the structural equation model (SEM) results suggested a relation between affinity for college, program engagement and support, and social-emotional outcomes. In addition, a CUB camp student's lack of a college major had a significant negative direct effect on some dimensions of affinity for college including college brand awareness, college relational expectations, and college academic interest-science. CUB camp providers can use the results of this study to better articulate how their programs might impact adolescent decision making related to college, as well as inform how CUB camp providers may intentionally create affinity spaces that maximize student awareness of college brands as well as their future expectations for the college experience.
\end{abstract}

Key words: affinity for college, pre-collegiate, career aspiration, camp, STEM

(cc) EY New articles in this journal are licensed under a Creative Commons Attribution 4.0 License. This journal is published by the University Library System, University of Pittsburgh and is cosponsored by the University of Pittsburgh Press. The Journal of Youth Development is the official peer-reviewed publication of the National Association of Extension 4-H Youth Development Professionals and the National AfterSchool Association. 


\section{Cultivating Youth Affinity for College}

\section{Introduction}

College and university-based (CUB) summer camps have emerged as a prominent out-of-school (OST) experience available to youth (American Camp Association, 2018). While most CUB camps occur on college or university campuses, other such programs may be offered at offcampus sites. CUB camps target outcomes for middle and high school youth that include enhancing college aspirations and preparedness for post-high school life (Bourdeau et al., 2014; Kirk \& Day, 2011), developing academic knowledge and skills (e.g., Fields, 2009), improving social-emotional skills (Bourdeau et al., 2014), and influencing future career choices (Bhattacharyya et al., 2011). In addition, many CUB camps seek to cultivate future student interest, thereby serving as an indirect recruitment tool for the college or university hosting the camp (Fields, 2009; Walsh et al., 2017). Research suggests CUB camps target both macro-level outcomes (e.g., academically engaging and recruiting future students) as well as individual-level outcomes (e.g., growth in academic interest or social-emotional skills), while providing potential students with a higher-education "taste-test." The importance of targeting such outcomes is magnified by literature indicating that nearly a quarter of high school seniors are not college ready (Venezia \& Jaeger, 2013). Perhaps most importantly, CUB camps are provided in a noncompetitive OST setting where learning can occur without pressures associated with school (Riedinger, 2015).

Given the rapid development of CUB camps as a strategy to foster socioemotional and academic performance in addition to their potential as recruiting tools, and the limited evidence of these potential impacts in the associated literature, the purpose of this study was to examine the relation between affinity for college, program engagement and support, college-major selection, socio-emotional learning (SEL) outcomes, and individual youth characteristics associated with CUB camp participation. The following research questions were explored:

1. What is the relation between affinity for college and program engagement and support within the context of a CUB camp program?

2. What is the relation between affinity for college and college major selection within the context of a CUB camp program?

3. What is the relation between youth age, affinity for college, and social-emotional learning within the context of a CUB camp program?

4. What is the relation between youth age and social-emotional learning within the context of a CUB camp program? 


\section{Cultivating Youth Affinity for College}

\section{Literature Review}

The following section provides an overview of literature supporting constructs associated with the study research questions, including affinity for college, college major selection, program engagement and support, academic and socio-emotional learning, and the youth characteristic of age.

\section{Affinity for College}

Affinity for college has its conceptual origins in the organizational affinity literature. Organizational affinity describes the attachment a person feels towards an organization because of their experience with or exposure to that organization (Oberecker et al., 2008). This affinity may also influence whether a person identifies with the organization (Aspara et al., 2008). Research suggests college and university-based programs serving adolescents may influence college-related youth beliefs, including attitudes toward a college brand (Walsh et al., 2017), feelings toward college as the "right fit" for them (Gibbons \& Borders, 2010), and opportunities to build relationships and participate in social activities (Shoffner et al., 2015). However, few studies have targeted the possible influence of CUB camp participation on organizational affinity. For example, Fields (2009) examined how participation in a CUB science summer camp influenced youths' future intentions with emergent themes that reflected organizational affinity (e.g., peer and staff relationships, personal autonomy, knowledge), but did not measure affinity towards the institution. From here forward "organizational affinity" is referred to as "affinity for college," as this concept provides the theoretical frame for the current study to describe how CUB camp participation may influence participants' perceptions of the college or university hosting their CUB camp.

\section{College Major Selection}

Within the context of CUB camps, affinity for college can be influenced by youth beliefs towards college such as the college major they intend to pursue (Geckova et al., 2010). One example of a belief youth might have toward college would be the major they intend to pursue (i.e., college major selection). Research suggests that uncertainty related to college major selection may be negatively related to youth success, as youth without a plan for their college major may be less prepared to meet degree requirements and therefore may have lower levels of affinity for college (Porter \& Umbach, 2006). This research suggests a negative relation between affinity for college and college major selection when youth do not have a plan for their college major. Some studies of the influence of CUB camp participation on college-related youth beliefs have had methodological limitations, such as the use of one-item measures (Bourdeau et al., 2014). 


\section{Cultivating Youth Affinity for College}

Limited response variation as a result of one-item measures makes it challenging to discriminate participant responses at the top of the scale (Bandalos, 2018). Limitations such as this within the CUB camp literature provides an opportunity in the current study to better understand how youth interest in a college major may be related to affinity for college within the context of a CUB camp experience.

\section{Program Engagement and Support}

Interdisciplinary literature supports the important role of program engagement and support on youth program outcomes, including evidence from implementation science (Berkel et al., 2011), youth development (Smith et al., 2006), and higher education (Tovar, 2015). Findings suggest that when youth are actively engaged by responsive instructors and provided with group discussion and collaborative activities, then positive youth outcomes like satisfaction, motivation, and increases in basic psychological needs (BPN) may result (León et al., 2015; Su \& Reeve, 2010; Tovar, 2015; Trenshaw et al., 2016). Although many of these factors have not been examined within CUB camps, the extant literature supports that a fully engaged and supported young person participating in a properly structured CUB camp, and who is also satisfied with the program, may have greater perceptions of their BPN being met and more positive perceptions of affinity for college. The current study examines how youth affinity for college may be associated with program engagement and support within the context of a CUB camp.

\section{Social-Emotional Learning}

While the influence of CUB camps on youth academic learning and social-emotional learning outcomes has been identified as an important area of study (National Academies of Sciences, Engineering, and Medicine 2019), research on youth academic learning outcomes (i.e., subject matter knowledge, future academic interest) as well as on social-emotional learning (SEL) outcomes (e.g., self and social awareness, emotional management, relationship skills; Weissberg et al., 2015) associated with CUB camp involvement has been limited. CUB camp studies generally target subjects such as science (Bhattacharyya \& Mead, 2011) and measure growth in academic skills (Hay \& Barab, 2001) or subject matter appeal (Bhattacharyya \& Mead, 2011) without examining future college academic interest and affinity for college that may be associated with skill development. Additionally, limited and mixed evidence exists regarding SEL outcomes resulting from CUB camp participation. For instance, while Fields (2009) found positive peer relationships were associated with CUB camp participation, Hay and Barab (2001) did not report growth in "socially negotiated outcomes" (p. 300) resulting from such program participation. 


\section{Cultivating Youth Affinity for College}

A promising approach for investigating SEL outcomes associated with CUB camp involvement is through the lens of BPN, comprised of autonomy, relatedness, and competence (Chen, 2015).

Research supports the positive relation between BPN and social-emotional and behavioral functioning (Saeki \& Quirk, 2015; Tarbetsky et al., 2017), with BPN serving as a mediator between youth engagement and SEL (Saeki \& Quirk, 2015). In addition, BPN has served as a conceptual and methodological scaffold for studies of camp experiences (Gagnon et al., 2019; Hill et al., 2015). The possible influence of CUB camp involvement on BPN is bolstered by studies suggesting CUB camps can increase youth competence and autonomy (Bourdeau et al., 2014; Fields, 2009). Recognizing that growth in outcomes may increase youth satisfaction with the CUB camp (Walsh et al., 2017) as well as youth future intention to attend college (Bourdeau et al., 2014), the current study examines the relation between growth in basic psychological needs and affinity for college.

\section{Youth Age}

Individual characteristics of youth such as age and gender can predict youth outcomes and college-related beliefs such as affinity for college (Porter \& Umbach, 2006; Washburn et al., 2011). While some studies suggest individual youth characteristics are positively related to youth outcomes (Eccles et al., 2004), other studies provide contrasting findings (Gagnon \& Sandoval, 2020). For example, as youth age increases, research suggests their positive perceptions of program outcomes tend to decrease (Phelps et al., 2009; Washburn et al., 2011) and correspondingly research suggests youth experience declines in developmental outcomes (Washburn et al., 2011). One possible explanation for this decline relates to developmental systems theory, where the potential positive influence of an experience (i.e., attending a CUB camp) on growth in outcomes "wears-off" as a young person encounters greater variation in activities as they mature (Lerner, 2018; Phelps et al., 2009). The current study examines the possible influence of age on youth SEL outcomes as well as their affinity for college within the context of a CUB camp experience.

\section{Method}

\section{Participants and Procedures}

The study took place in the summer of 2017 in partnership with two public universities (one in the southeastern United States and the other in the southwest United States) that operated multiple 1-week CUB camp sessions. Sessions were intentionally designed to expose youth to the college experience and provide access to science- and technology-related subject matter through interaction with university faculty and current college students. Prior to participant 


\section{Cultivating Youth Affinity for College}

recruitment and data collection the study was approved through the authors' Institutional Review Board. Youth and their parents were contacted by camp administrators and informed of the study through consent and assent letters.

Data were collected from 671 respondents across the two universities. Youth completed an online questionnaire on the last day of the CUB camp that measured demographics, affinity for college, program engagement and support, basic psychological needs, and college major selection.

After screening for outliers and normality (as described below), the final study sample was 641 for an overall response rate of $95.52 \%$. Study respondents tended to be female $(52.1 \%)$, to have an average age of 15.37 years $(S D=1.32)$, and to have an average of 1.33 years of CUB camp experience $(S D=.860)$. Respondents primarily identified as White $(68.7 \%)$, with the remaining sample identifying as African American (14.6\%), multiple race (5.8\%), Hispanic or Latino origin (4.5\%), Asian origin (3.9\%), Indian or Arabic origin (2.3\%), or Native American $(0.2 \%)$.

\section{Measures}

Measures used in this study included affinity for college, program engagement and support, college major selection, and basic psychological needs. These measures are described below.

\section{Affinity for College}

Within the context of a CUB camp experience, affinity for college was operationalized as feelings of attraction or attachment toward a college or university institution (Aspara, 2008; Oberecker et al.,2008). Based on prior research (Garst et al., 2019), affinity for college was theorized to be comprised of four factors: college brand awareness, college relational expectations, college academic interest-science, and college academic interest-technology. These factors are described below.

College Brand Awareness. College brand awareness was operationalized as perceiving a college brand as desirable. This 6-item subscale was informed by Walsh et al.'s (2017) "brand (team) attitudes" subscale ( $a=.94$ ) and Gibbons and Borders's (2010) College-Going Self-Efficacy Scale (persistence subscale, $a=.90)$. For example, Walsh et al.'s (2016) item, "The team brand is something I dislike/like" informed the item, "I have a positive view of [college]." As another example, Gibbons and Borders's (2010) item, "I would like being in college" informed the item, "I want to attend college." Items were measured on a 7-point Likert-type scale so youth 


\section{Cultivating Youth Affinity for College}

responses ranged from 1 (strongly disagree) to 7 (strongly agree), with higher scores representing higher levels of college brand awareness.

\section{College Relational Expectations. The college relational expectations measure was} operationalized as understanding the social/relational aspects of the college experience. This 7item subscale was informed by Shoffner et al.'s (2015) discussion of adolescents' future careerrelated relational outcome expectations (i.e., "ability to participate in social activities and engage in interpersonal relationships" [p. 108]). Sample items, measured on a 7-point Likerttype scale so youth responses ranged from 1 (strongly disagree) to 7 (strongly agree), included "I know what to do to make friends as a [college] student" and "I know what clubs to join as a [college] student."

\section{College Academic Interest-Science. College academic interest-science was operationalized as} broad interest in science-related courses, skills, and knowledge impacting one's future college or career plans. This 8-item scale was informed by the outcome expectancy/intentions and goals subscale $(a=.80)$ of Fouad et al.'s (1997) Middle School Self-Efficacy Scale. For example, Fouad et al.'s item, "If I do well in science, then I will be better prepared to go to college" informed the item "I would like to learn science-related knowledge and skills because they can be useful to help me be prepared for college." Items were measured on a 7-point Likert-type scale so youth responses ranged from 1 (strongly disagree) to 7 (strongly agree), with higher scores representing higher levels of college academic interest.

\section{College Academic Interest-Technology. College academic interest-technology was} operationalized as broad interest in technology-related courses, skills, and knowledge impacting one's future college or career plans. This 8-item scale was informed by the outcome expectancy/intentions and goals subscale $(a=.80)$ of Fouad et al.'s (1997) Middle School SelfEfficacy Scale. For example, Fouad et al.'s item, "I intend to enter a career that will use science" informed the item "I am interested in working in a career that allows me to use technologyrelated skills or knowledge." Items were measured on a 7-point Likert-type scale so youth responses ranged from 1 (strongly disagree) to 7 (strongly agree), with higher scores representing higher levels of college academic interest.

\section{Program Engagement and Support}

The program engagement and support measure was conceptualized as three factors impacting CUB camp participation: supportive camp counselor behaviors, supportive instructor behaviors, and camp structure engagement (Gagnon \& Sandoval, 2020). The first two factors were adapted from the personal development subscale of the Tiffany-Eckenrode Program 


\section{Cultivating Youth Affinity for College}

Participation Scale (TEPPS; Tiffany et al., 2012). These adaptations did not change the nature of the instrument. Expressly, the TEPPS' personal development subscale was modified to measure supportive camp counselor behaviors (e.g., "My counselor provided guidance about college."; 5 items) and supportive instructor behaviors (e.g., "My instructor allowed me to gain new knowledge."; 4 items). These subscales have exhibited acceptable internal consistency levels in previous studies ( $a=.849 ; .836)$. In addition to these counselor and instructor behavior subscales, items related to how the camp structure engagement was designed to enhance participant engagement were used (e.g., "The program provided a variety of activities."; 4 items). This subscale has demonstrated an acceptable level of internal consistency in previous studies $(a=.814)$. All items in this scale were measured on a Likert-type scale from 1 (strongly disagree) to 5 (strongly agree), where higher scores indicate greater participant satisfaction and engagement.

\section{College Major Selection}

To assess CUB camp participants' college major selection (as a characteristic that may predict youth outcomes and affinity for college; see Eccles et al., 2004), youth were asked to identify their desired college major based on categories informed by Wegemer and Eccles (2018). These college major selection categories included: HBMS (health, biological, and medical sciences), MPECS (mathematical, physical, engineering, and computer sciences), HBE (humanities, business, or education), and IDK (i.e., an "I don't know" type of response). Of all respondents $37.9 \%$ indicated a HBMS major, $42.1 \%$ indicated a MPECS major, $14.6 \%$ indicated a HBE major, and $5.4 \%$ indicated IDK.

\section{Basic Psychological Need Satisfaction and Frustration (BPNSF)}

SEL outcomes associated with CUB camp experiences were measured using the Basic Psychological Needs Satisfaction and Frustration Scale (BPNSF). Informed by Chen et al. (2015), the 24-item BPNSF scale measures outcomes (i.e., psychological need for autonomy, relatedness, and competence) influenced by the summer camp experience (Gagnon et al., 2019). These outcomes were measured on a 5-point Likert-type scale from 1 (completely untrue) to 5 (completely true) from the perspective of a youth's sense of satisfaction (i.e., BPN$S$; their need was met) or frustration (i.e., BPN-F, their need was not met) with the CUB camp experience. Items representing BPN-S included autonomy satisfaction (e.g., "I feel a sense of choice and freedom in the things I undertake."; $\lambda=.64-.76$, subscale $a=.81$ ), relatedness satisfaction (e.g., "I feel connected with people who care for me, and for whom I care."; $\lambda=$ $.66-.72$, subscale $a=.76$ ), and competence satisfaction (e.g., "I feel I can successfully complete difficult tasks."; $\lambda=.74-.80$, subscale $a=.88$ ). Conversely, BPN-F items representing 


\section{Cultivating Youth Affinity for College}

"ill-being" in three dimensions included autonomy frustration (e.g., "I feel forced to do many things I wouldn't choose to do"; $\lambda=.61-.69$, subscale $a=.71$ ), relatedness frustration (e.g., "I feel that people who are important to me are cold and distant towards me."; $\lambda=.64-.69$, subscale $a=.81$ ), and competence frustration (e.g., "I feel insecure about my abilities"; $\lambda=$ $.64-.74$, subscale $a=.86)$.

\section{Data Analyses}

\section{Outliers, Normality, and Missing Data}

Prior to analyses, data were screened for multivariate outliers utilizing a combination of the Mahalanobis distance function and chi-square distribution test $(p<.001)$ in SPSS 24 software (Field, 2018). This analysis suggested 18 respondents were significant outliers and were thus removed from the data set. The data were then screened for multivariate nonnormality and missing data patterns utilizing the MissMech package (version 1.0.2; Jamshidian \& Jalal, 2010) in RStudio (version 1.2.5042). This analysis suggested the data were multivariate non-normal (Hawkins test, $p<.001$ ). As such a robust maximum likelihood framework was employed to mitigate potential Type 1 error in model interpretation (Bentler, 2006).

The data were next screened to determine potential causes of missing data (i.e., missing completely at random [MCAR]; missing at random [MAR]; missing not at random [MNAR]) utilizing a nonparametric version of Little's test of MCAR (Jamshidian \& Jalal, 2010; Little,1988) This test indicated the data were MCAR $(p=.327)$, thus a full information maximum likelihood (FIML) approach was employed to simulate missing values within the data set (Enders, 2010).

\section{Measurement Model Testing}

The measurement properties of the questionnaire were examined through a confirmatory factor analysis (CFA) utilizing the Lavaan package (version 0.6-5; Rosseel, 2012) in RStudio with a robust estimation approach (i.e., MLR). The initial CFA exhibited relatively poor fit, with the following CFA fit statistics calculated as: Satorra-Bentler $X^{2}(1283)=3123.530, p<.001$, CFI $=$ $.890, \mathrm{TLI}=.882, \mathrm{RMSEA}=.047(90 \%, \mathrm{CI} .045$ to .049$)$. Inspection of the factor loadings suggested two items within the measurement model were demonstrating poor fit: one item from the supportive instructor behaviors factor ("The courses were challenging."; $\lambda=.370$ ), and one item from the first order autonomy frustration factor ("Most of the things I do, feel like 'I have to."'; $\lambda=.501$ ). The modification indices did not suggest the re-specification of the two items to alternative factors would result in meaningful improvement in model fit in parallel with the hypothesized model framework. Further review of the modification indices also suggested one item within the first-order autonomy satisfaction factor ("I feel a sense of choice and 


\section{Cultivating Youth Affinity for College}

freedom in the things I undertake.") was sharing external variance with several additional factors within the model (i.e., supportive camp counselor behaviors; camp structure engagement; college relational expectations) also harming measurement model fit. As such these items were removed from the measurement model. Additional examination of the modification indices suggested five pairs of items were sharing a significant proportion of variance external of their suggested factors. Inspection of the item wordings suggested a high degree of similarity across the item pairs, as such their error terms were covaried. These modifications to the measurement model resulted in acceptable levels of model fit: SatorraBentler $X^{2}(1177)=2618.632, p<.001$, CFI $=.912$, TLI $=.904$, RMSEA $=.044$ (90\%, CI .042 to .046) and factor structure (Table 1).

Table 1. Between-Factor Correlations

\begin{tabular}{|l|l|l|l|l|l|l|l|l|l|}
\hline & \multicolumn{1}{|c|}{$\begin{array}{c}\text { F1 } \\
\text { SCB }\end{array}$} & $\begin{array}{c}\text { F2 } \\
\text { CSE }\end{array}$ & \multicolumn{1}{|c|}{$\begin{array}{c}\text { F3 } \\
\text { SIB }\end{array}$} & $\begin{array}{c}\text { F4 } \\
\text { CBA }\end{array}$ & $\begin{array}{c}\text { F5 } \\
\text { CRE }\end{array}$ & $\begin{array}{c}\text { F6 } \\
\text { CAIS }\end{array}$ & $\begin{array}{c}\text { F7 } \\
\text { CAIT }\end{array}$ & $\begin{array}{c}\text { F8 } \\
\text { BPNS }\end{array}$ & $\begin{array}{c}\text { F9 } \\
\text { BPNF }\end{array}$ \\
\hline F1 & .692 & & & & & & & & \\
\hline F2 & $.572 * * *$ & .746 & & & & & & & \\
\hline F3 & $.304 * * *$ & $.363 * * *$ & .640 & & & & & & \\
\hline F4 & $.371 * * *$ & $.381 * * *$ & $.162 * *$ & .712 & & & & & \\
\hline F5 & $.611 * * *$ & $.532 * * *$ & $.183 * *$ & $.880 * * *$ & .691 & & & & \\
\hline F6 & .079 & $.218 * * *$ & $.138 * *$ & $.150 * *$ & $.174 * * *$ & .937 & & & \\
\hline F7 & .064 & $.133 * *$ & .011 & .038 & $.101 *$ & $.112 * *$ & .915 & & \\
\hline F8 & $.384 * * *$ & $.540 * * *$ & $.437 * * *$ & $.427 * * *$ & $.448 * * *$ & $.194 * * *$ & $.089 *$ & .884 & \\
\hline F9 & $-.359 * * *$ & $-.411 * * *$ & $-.279 * * *$ & $-.262 * * *$ & $-.274 * * *$ & $-.144 * *$ & -.002 & $-.629 * * *$ & .871 \\
\hline
\end{tabular}

Note. SCB = Supportive Camp Counselor Behaviors; CSE = Camp Structure Engagement; SIB = Supportive Instructor Behaviors; $\mathrm{CBA}=$ College Brand Awareness; $\mathrm{CRE}=$ College Relational Expectations; CAIS = College Academic Interest-Science; CAIT = College Academic Interest-Technology; BPNS = Basic Psychological Needs Satisfaction; BPNF = Basic Psychological Needs- Frustration $* p<.05, * * p<.01, * * * p<.001$

\section{Results}

A structural equation model (SEM) was developed to assess relations proposed in the study research questions. Paralleling the measurement model fit, the SEM exhibited acceptable model fit: Satorra-Bentler $X^{2}(1250)=2665.280, p<.001$, CFI $=.920$, TLI $=.908$, RMSEA $=.042$ $(90 \%, \mathrm{CI} .040$ to .044$)$. The results are presented below according to each research question. 


\section{Cultivating Youth Affinity for College}

Research Question \#1: What is the relation between affinity for college and program engagement and support within the context of a CUB camp program?

Supportive camp counselor behaviors significantly predicted college brand awareness $(\beta=.194$, $S E=.078, p=.004)$ and college relational expectations $(\beta=.436, S E=.100, p<.001)$, but had no predictive effect on college academic interest-technology $(\beta=-.046, S E=.068, p=$ .399 ) or college academic interest-science $(\beta=-.047, S E=.076, p=.532)$. Camp structure engagement had a significant positive direct effect on college brand awareness $(\beta=.264, S E=$ $.085, p<.001)$, college relational expectations $(\beta=.306, S E=.097, p<.001)$, college academic interest-technology $(\beta=.179, S E=.074, p=.002)$, and college academic interestscience $(\beta=.172, S E=.073, p=.019)$. Additionally, camp structure engagement had a significant positive direct effect on BPN-Satisfaction $(\beta=.335, S E=.098, p<.001)$. Supportive instructor behaviors had no effect on college brand awareness $(\beta=-.021, S E=.062, p=$ $.688)$, college relational expectations $(\beta=-.075, S E=.072, p=.157)$, college academic interest-technology $(\beta=.073, S E=.058, p=.112)$, and college academic interest-science) $(\beta$ $=-.011, S E=.057, p=.852)$, but had a significant positive direct effect on BPN-Satisfaction $(\beta$ $=.254, S E=.078, p<.001)$.

\section{Research Question \#2: What is the relation between affinity for college and college major selection within the context of a CUB camp program?}

College major selection (MPECS vs. IDK) had a significant negative direct effect on college brand awareness $(\beta=-.228, S E=.183, p<.001)$, college relational expectations $(\beta=-.151$, $S E=.25, p<.001)$, college academic interest-science $(\beta=-1.037, S E=.185, p<.001)$, but no effect on college academic interest-technology $(\beta=-.034, S E=.208, p=.368)$. College major selection (MPECS vs. HBE) had no effect on college brand awareness ( $\beta=-.105, S E=$ $.144, p=.015)$ or college relational expectations $(\beta=-.039, S E=.166, p=.359)$, a significant negative direct effect on college academic interest-technology $(\beta=-.37, S E=.164, p=$ $<.001)$, and significant positive direct effect on college academic interest-science) $(\beta=.883$, $S E=.136, p<.001)$. Finally, college major selection (MPECS vs. HBMS) had no effect on college brand awareness $(\beta=-.023, S E=.103 p=.592)$, or college relational expectations ( $\beta$ $=-.011, S E=.128, p=.811)$, and a significant positive direct effect on college academic interest-technology $(\beta=.324, S E=.087, p<.001)$ and college academic interest-science $(\beta=$ $.985, S E=.101, p<.001)$. 


\section{Cultivating Youth Affinity for College}

Research Question \#3: What is the relation between youth age, affinity for college, and social-emotional learning within the context of a CUB camp program?

Youth age had a significant positive direct effect on college brand awareness $(\beta=.165, S E=$ $.036, p<.001)$, but no effect on college relational expectations $(\beta=.114, S E=.04, p=.003)$, college academic interest-science $(\beta=.023, S E=.032, p=.473)$, and college academic interest-technology $(\beta=.031, S E=.033, p=.364)$. In addition, youth age had no effect on BPN-satisfaction $(\beta=.01, S E=.040, p=.815)$ or BPN-frustration $(\beta=-.107, S E=.037, p=$ $.012)$.

Research Question \#4: What is the relation between affinity for college and socialemotional learning within the context of a CUB camp program?

College brand awareness did not significantly predict either BPN-satisfaction $(\beta=.386, S E=$ $.276, p=.539)$ or BPN-frustration $(\beta=-.385, S E=.263, p=.148)$. Similarly, college relational expectations had no effect on BPN Satisfaction $(\beta=-.191, S E=.288, p=.539)$ or BPN Frustration $(\beta=-.107, S E=.037, p=.012)$.

\section{Discussion}

\section{Affinity for College}

This study explored the influence of participation in a common summertime youth development program-college and university-based (CUB) summer camps-on youth perceptions of the college or university hosting the camp and outcomes associated with program participation. Possible relations between affinity for college, college major selection, program engagement and support, and SEL outcomes (i.e., basic psychological needs) stemming from youth involvement in a CUB camp were examined.

This study first validated through CFA the 'affinity for college' construct within a large sample of CUB camp youth, extending the work of Garst et al. (2019). The four-factor model was comprised of college brand awareness, college relational expectations, college academic interest-science, and college academic interest-technology. Although this study was one of the first examinations of affinity for college within a CUB camp, the findings support Walsh et al. (2017) who suggested that a youth camp experience can build brand loyalty, in this case enhancing youth attraction toward the college or university hosting the CUB camp. Further, this study's findings suggest that program-level features such as developing peer relationships and engagement with current college students enhanced the likelihood participants would engage with the universities hosting the CUB camp in the future. 


\section{Cultivating Youth Affinity for College}

However, the differing effects of college major selection in the SEM results suggest additional unique variance and/or interpretation of the items by youth with differing majors. The college academic interest-science and college academic interest-technology factors of affinity for college were oriented only towards science or technology; given the near ubiquity of how STEM is conceptualized as a universal construct (Ganley et al., 2018) rather than science and/or technology and/or engineering and/or math, future investigations should explore academic interests to include majors beyond those traditionally associated with STEM career paths (Wang \& Degol, 2017; Wegemer \& Eccles, 2019).

\section{Social-Emotional Outcomes}

The study findings supported the relation between affinity for college and increases in the SEL outcomes of BPN (i.e., autonomy, relatedness, and competence), effects that were positively correlated but non-significant. This positive correlation between CUB camp participation and SEL outcomes supports Fields' (2009) and Gee's (2018) discussion of the role of affinity spaces (e.g., CUB camps) in fostering positive youth outcomes, and further validates research suggesting camp experiences may enhance BPN (Gagnon et al., 2019; Hill et al., 2015). While this study supports research suggesting BPN-type outcomes may result from CUB camp participation (Bourdeau et al., 2014; Fields, 2009), the non-significant SEL findings may point to the salience of other (non-SEL) outcomes. For example, it may be that CUB camp participation is more impactful on academic or subject-matter knowledge outcomes (Fields, 2009) as well as career choice (Bhattacharyya et al., 2011) rather than SEL outcomes.

\section{Engagement and Support}

This study expands upon Fields's (2009) findings that CUB camps are affinity spaces by providing evidence that specific program elements (e.g., supportive camp counselor behaviors, supportive instructor behaviors, and camp structure engagements) contribute to youth perceptions of attachment toward the college that hosts the CUB camp. This finding supports how positive relationships are formed between youth, counselors, and instructors within the context of CUB camps, and aligns with broader camp research identifying relationship building as a critical dimension of the camp experience (Gillard et al., 2009; Wilson \& Sibthorp, 2018) that may increase youth attachment to camp as an impactful place/affinity space (Dahl, 2009). Additionally, the negative correlation between camp structure engagement and BPNF is consistent with previous studies indicating that positive outcomes result when youth are properly engaged and supported (Gasiewski et al., 2012; León et al., 2015), and likewise that negative outcomes would result when youth are not properly engaged and supported. This finding provides the first such evidence of this correlation within the context of CUB camps. 


\section{Cultivating Youth Affinity for College}

\section{College Major}

A CUB camp participant's lack of college major negatively predicted their affinity for college. In other words, youth who had not identified a college major were less likely to perceive affinity for college. This finding supports Porter and Umbach's (2006) perspective of college major uncertainty and the lack of future preparedness accompanying a sense of uncertainty toward college. Not having a plan for college, such as an identified college major, may reduce youth future college beliefs including their attraction to or affinity for college. In contrast, encouraging youth to develop a plan for college, starting with identifying a college major, may influence emergence of affinity for colleges and universities offering that major among youth participating in a CUB camp experiences. Youth development program providers are well positioned to engage youth in programs and experiences that influence their future decisions college and career decision (Bhattacharyya et al., 2011; Habig et al., 2020; Whittington \& Garst, 2018).

\section{Youth Characteristics}

As predicted, youth age negatively predicted some affinity for college factors (i.e., college relational expectations, college academic interest-science, and college academic interesttechnology). In other words, younger youth participating in the CUB camp were more likely to indicate affinity for college in these areas than older youth participating in the CUB camp. This negative relation supports prior studies suggesting that as youth age increases, perceptions of a program may decline as the program becomes less challenging, varied, or novel (Gagnon \& Sandoval, 2020; Washburn et al., 2011). However, the significant positive direct effect of youth age on the college brand awareness factor suggests that this dimension of affinity for college may be enhanced as youth get older, possibly reflecting ongoing exposure to the college brand or increased interest in the brand as youth get closer in age to making a college decision. It is notable that youth age had no effect on SEL outcomes (i.e., autonomy, relatedness, and competence), which is contrary to previous research (Washburn et al., 2011).

\section{Implications for Research and Practice}

Findings from this study are important for both research and practice. First, this study provides methodological confirmation that affinity for college can be measured within the context of CUB camps using a multi-factor model, offering another way that such camp experiences may be evaluated. Specifically, the possible relation between affinity for college and other dimensions of the CUB camp experience (e.g., customer satisfaction, retention over time) can now be explored using the measure validated in this study. Future research could explore, for example, how youth program participation in OST programs such as CUB camps may influence not only 


\section{Cultivating Youth Affinity for College}

how participants develop an affinity for an organizational brand, but also how their friends and family may come to perceive the brand through socialization and internalization processes (Richelieu \& Pons, 2011). Such research suggests a way friends and family might develop a stronger attachment to a CUB camp (and to the college or university hosting the camp) because a family member was participating in the program. Further, as research suggests a relation between college major interest and future aspirations (Nauta \& Epperson, 2003), future research could examine whether affinity for college moderates (i.e., strengthens) the relation between college major interest expressed during a CUB camp experience and future career and college aspirations. Research suggesting such a relation would indicate empirically how CUB camp participation may influence career choice as suggested by Bhattacharyya et al. (2011).

Second, practitioners can use the study results to better articulate in their program marketing materials how their CUB camp programs might impact adolescent decision making related to college, as well as how CUB camps are affinity spaces that maximize the dimensions of college brand awareness and college relational expectations. Further, the study findings suggest that when CUB camps recruit youth into their program with the goal of cultivating future undergraduate students, they should focus on youth who have a specific interest area targeted for college

Third, CUB camp practitioners interested in determining how their targeted outcomes may be influenced by affinity for college can use the results of this study (specifically, the relation between affinity for college, SEL outcomes, and engagement and structure) as a starting point in mapping intentional outcomes to CUB camp program components. Such mapping can inform logic models to guide CUB camp program quality and effectiveness.

Fourth, the study findings support practitioner efforts to emphasize relationship building between CUB camp participants and current college students, as such engagement may increase youth future interest in the college or university hosting the program. Youth development practitioners can play an important role in helping youth see higher education as a potential future path, but as Oliveri et al. (2018) suggest, "high school and college are two separate worlds, with different origins and purposes" (p. 45). Encouraging youth to see a college or university experience as part of their future requires program providers to bridge this divide. Intentional programming to provide youth with meaningful opportunities to learn about the college and university experience directly from current college students-including academics and extra-curricular and social activities-may have both short-term (e.g., program engagement during middle or high school years) and long-term (e.g., college or university enrollment) benefits. 


\section{Cultivating Youth Affinity for College}

Fifth, this study adds to the body of knowledge related to how CUB camps may influence outcomes. Given that affinity for college and BPN were positively correlated but non-significant, replication of the current study with other youth populations may affirm or disprove relation between affinity for college and BPN within the context of CUB camps. Given the findings of this study, future replication may indicate that CUB camps are more impactful on non-SEL outcomes. CUB camp practitioners may consider what programmatic approaches may be effective for enhancing (BPN-related) SEL outcomes, if enhancing such outcomes is a program goal. In addition, examining affinity for college in youth populations representing underserved or low-resourced communities may be helpful for informing how youth development programs such as CUB camps may be influential in building youth affinity for college within those populations. Such an application of a diversity, equity, and inclusion (DEI) lens to the affinity for college construct may broaden the usefulness of the construct for the youth development field.

\section{Limitations and Future Directions}

Several limitations are acknowledged. First, this study utilized a cross-sectional design in which data were collected from CUB camp participants only at the end of the camp session. Although this approach is common among studies of youth camp experiences (Schmalz et al., 2011; Wilson \& Sibthorp, 2018), it limits pre-post comparisons of the study variables. Longitudinal designs in future studies of affinity for college would allow for a more thorough understanding of the durability of changes in perceptions of affinity for college resulting from CUB camp experiences. As suggested by Oberecker et al. (2008), affinity is "enduring but not irrevocable" (p. 43). If a CUB camp participant or their parent has a negative experience at the CUB camp or the institution hosting the camp, then perceptions of affinity may decline. A longitudinal design would allow for an examination of the relation between affinity for college and college retention (Kirk \& Day, 2011), which may be of particularly interest to colleges and universities seeking to turn summer CUB camp participants into full-time, tuition-paying undergraduates. Second, correlates that were not measured may have accounted for lack of effects. For example, there may be a relation between affinity for college and self-identity (Riedinger, 2015) or between affinity for college and academic knowledge and skills (Fields, 2009). Other relations of interest in future studies of CUB camp participants could include the possible relation between affinity for college and academic readiness (Wilson \& Sibthorp, 2018).

\section{Conclusions}

Given the challenges facing educators and students within higher education due to the COVID19 crisis, including enrollment declines (Bulman \& Fairlie, 2021; Kwakye et al., 2021) and unexpected and unplanned transitions to virtual instruction (Camilleri, 2021; Murphy et al., 
2020), a deeper understanding of factors and programs that promote future youth engagement with a college or university has become more critical. Colleges and universities need strategies to engage middle and high school-aged youth that encourage them to see higher education as a part of their future, particularly within the context of COVID-19 in which youth may feel uncertain about their academic path following high school. This study introduces affinity for college as a meaningful construct for understanding CUB camp experiences and provides evidence for variables influencing affinity for college. By establishing relations between affinity for college, program engagement and support, and SEL outcomes, this study provides a compelling foundation for future research into affinity for college as well as a new lens for evaluating CUB camps and similar OST experiences hosted on college and university campuses.

\section{References}

American Camp Association. (2018). Camps on campus. (https://www.acacamps.org/resourcelibrary/professional-development/camps-campus)

Aspara, J., Olkkonen, R., Tikkanen, H., Moisander, J., \& Parvinen, P. (2008). A theory of affective selfaffinity: Definitions and application to a company and its business. Academy of Marketing Science Review, 12(3). (https://www.amsweb.org/page/OriginalAMSR/articles/aspara03-2008.pdf)

Bandalos, D. L. (2018). Measurement theory and applications for the social sciences. Guilford.

Bentler, P. M. (2006). EQS 6 Structural Equations Program Manual. Multivariate Software, Inc.

Berkel, C., Mauricio, A. M., Schoenfelder, E., \& Sandler, I. N. (2011). Putting the pieces together: An integrated model of program implementation. Prevention Science, 12(1), 23-33. (https://doi.org/10.1007/s11121-010-0186-1)

Bhattacharyya, S., Mead, T. P., \& Nathaniel, R. (2011). The influence of science summer camp on African-American high school students' career choices. School Science and Mathematics, 111(7), 345-353. (https://doi.org/10.1111/j.1949-8594.2011.00097.x)

Bourdeau, V. D., Galloway, R., Arnold, M., \& Nott, B. D. (2014). Impact of a middle school 4-H science camp on college aspirations of alumni. Journal of Extension, 52(1), 1-8.

Bulman, G., \& Fairlie, R. W. (2021). The impact of COVID-19 on community college enrollment and student success: Evidence from California administrative data (No. w28715). National Bureau of Economic Research.

Camilleri, M. A. (2021). Evaluating service quality and performance of higher education institutions: A systematic review and a post-COVID-19 outlook. International Journal of Quality and Service Sciences, 13(2), 268-281. (https://doi.org/10.1108/IJQSS-03-2020-0034)

Chen, B., Vansteenkiste, M., Beyers, W., Boone, L., Deci, E. L., Van der Kaap-Deeder, J., Duriez, B., Lens, W., Matos, L., Mouratidis, A., Ryan, R., Sheldon, K. M., Soenens, B., Van Petegem, S., \&Verstuyf, 
Journal of Youth Development | http://jyd.pitt.edu/ | Vol. 16 Issue 5 DOI 10.5195/jyd.2021.1083 Cultivating Youth Affinity for College

J. (2015). Basic psychological need satisfaction, need frustration, and need strength across four cultures. Motivation and Emotion, 39(2), 216-236. (https://doi.org/10.1007/s11031-014-9450-1)

Dahl, T. I. (2009). The importance of place for learning about peace: Residential summer camps as transformative thinking spaces. Journal of Peace Education, 6(2), 225-245.

Eccles, J. S., Vida, M. N., \& Barber, B. (2004). The relation of early adolescents' college plans and both academic ability and task-value beliefs to subsequent college enrollment. The Journal of Early Adolescence, 24(1), 63-77.

Enders, C. K. (2010). Applied missing data analysis. The Guilford Press

Field, A. (2018). Discovering statistics using IBM SPSS statistics (5 ${ }^{\text {th }}$ ed.). Sage.

Fields, D. A. (2009). What do students gain from a week at science camp? Youth perceptions and the design of an immersive, research-oriented astronomy camp. International Journal of Science Education, 31(2), 151-171. (https://doi.org/10.1080/09500690701648291)

Fouad, N. A., Smith, P. L., \& Enochs, L. (1997). Reliability and validity evidence for the middle school selfefficacy scale. Measurement and Evaluation in Counseling and Development, 30(1), 17-23. (https://doi.org/10.1080/07481756.1997.12068914)

Gagnon, R. J., \& Sandoval, A. (2020). Pre-college STEM camps as developmental context: Mediational relations between gender, career decidedness, socioemotional development, and engagement. Children and Youth Services Review, 108. (https://doi.org/10.1016/j.childyouth.2019.104584)

Gagnon, R. J., Garst, B. A., \& Townsend, J. A. (2019). Tough decisions in medical specialty camps: Relationships between camp dosage, outcomes, and camper attendance. Social Science \& Medicine, 221, 49-57. (https://doi.org/10.1016/j.socscimed.2018.12.014)

Ganley, C. M., George, C. E., Cimpian, J. R., \& Makowski, M. B. (2018). Gender equity in college majors: Looking beyond the STEM/non-STEM dichotomy for answers regarding female participation. American Educational Research Journal, 55(3), 453-487. (https://doi.org/10.3102/0002831217740221)

Garst, B., Gagnon, R., Woodward, J., \& Bowen, M. (2019). Building organizational affinity: The relationship between affinity for college and youth outcomes within the context of universitybased summer camps. 2019 American Camp Association Research Forum Abstracts (pp. 41-43). (https://www.acacamps.org/sites/default/files/resource_library/2019-National-Research-ForumBook-Abstracts.pdf)

Gasiewski, J. A., Eagan, M. K., Garcia, G. A., Hurtado, S., \& Chang, M. J. (2012). From gatekeeping to engagement: A multicontextual, mixed method study of student academic engagement in introductory STEM courses. Research in Higher Education, 53(2), 229-261. (https://doi.org/10.1007/s11162-011-9247-y) 
Journal of Youth Development | http://jyd.pitt.edu/ | Vol. 16 Issue 5 DOI 10.5195/jyd.2021.1083 Cultivating Youth Affinity for College

Geckova, A. M., Tavel, P., van Dijk, J. P., Abel, T., \& Reijneveld, S. A. (2010). Factors associated with educational aspirations among adolescents: cues to counteract socioeconomic differences? $B M C$ Public Health, 10(154). (https://doi.org/10.1186/1471-2458-10-154)

Gee, J. P. (2018). Affinity spaces: How young people live and learn on line and out of school. Phi Delta Kappan, 99(6), 8-13. (https://doi.org/10.1177/0031721718762416)

Gibbons, M., \& Borders, L. (2010). A measure of college-going self-efficacy for middle school students. Professional School Counseling, 13(4), 234-243.

Gillard, A., Watt, C. E., \& Witt, P. A. (2009). Camp supports for motivation and interest: A mixed-methods study. Journal of Park and Recreation Administration, 27(2), 74-96.

Habig, B., Gupta, P., Levine, B., \& Adams, J. (2020). An informal science education program's impact on STEM major and STEM career outcomes. Research in Science Education, 50(3), 1051-1074. (https://doi.org/10.1007/s11165-018-9722-y)

Hay, K.E., \& Barab, S.A. (2001). Constructivism in practice: A comparison and contrast of apprenticeship and constructionist learning environments. The Journal of the Learning Sciences, 10(3), 281-322. (https://doi.org/10.1207/S15327809JLS1003_3)

Hill, E., Gagnon, R., Ramsing, R., Goff, J., Kennedy, B., \& Hooker, T. (2015). Measuring the impact of a medical specialty camp. Therapeutic Recreation Journal, 49(4), 310-325.

Jamshidian, M., \& Jalal, S. (2010). Tests of homoscedasticity, normality, and missing completely at random for incomplete multivariate data. Psychometrika, 75(4), 649-674. (https://doi.org/10.1007/s11336-010-9175-3)

Kirk, R., \& Day, A. (2011). Increasing college access for youth aging out of foster care: Evaluation of a summer camp program for foster youth transitioning from high school to college. Children and Youth Services Review, 33(7), 1173-1180. (https://doi.org/10.1016/j.childyouth.2011.02.018)

Kwakye, I., Kibort-Crocker, E., Lundgren, M., \& Pasion, S. (2021). Fall enrollment report: Exploring the impact of COVID-19 on postsecondary enrollment in Washington. Washington Student Achievement Council. (https://wsac.wa.gov/sites/default/files/2021-01-12-Fall-EnrollmentReport.pdf)

León, J., Núñez, J. L., \& Liew, J. (2015). Self-determination and STEM education: Effects of autonomy, motivation, and self-regulated learning on high school math achievement. Learning and Individual Differences, 43, 156-163. (https://doi.org/10.1016/j.lindif.2015.08.017)

Lerner, R. M. (2018). Concepts and theories of human development. Routledge.

Little, R. J. A. (1988). A test of missing completely at random for multivariate data with missing values. Journal of The American Statistical Association, 83(404), 1198-1202. (https://doi.org/10.1080/01621459.1988.10478722) 
Journal of Youth Development | http://jyd.pitt.edu/ | Vol. 16 Issue 5 DOI 10.5195/jyd.2021.1083 Cultivating Youth Affinity for College

Murphy, L., Eduljee, N. B., \& Croteau, K. (2020). College student transition to synchronous virtual classes during the COVID-19 pandemic in Northeastern United States. Pedagogical Research, 5(4), em0078. (https://doi.org/10.29333/pr/8485)

National Academies of Sciences, Engineering, and Medicine. (2019). Shaping summertime experiences: Opportunities to promote healthy development and well-being for children and youth. The National Academies Press. (https://doi.org/10.17226/25546)

Nauta, M. M., \& Epperson, D. L. (2003). A longitudinal examination of the social-cognitive model applied to high school girls' choices of nontraditional college majors and aspirations. Journal of Counseling Psychology, 50(4), 448. (https://psycnet.apa.org/doi/10.1037/0022-0167.50.4.448)

Oberecker, E. M., Riefler, P., \& Diamantopoulos, A. (2008). The consumer affinity construct: Conceptualization, qualitative investigation, and research agenda. Journal of International Marketing, 16(3), 23-56. (https://doi.org/10.1509/jimk.16.3.23)

Oliveri, C., Funke, K., Clark, J., \& Seifert, T. A. (2018). Blueprints for student success: High school students' questions about the transition to college. Journal of College Orientation, Transition, and Retention, 25(1), 43-59. (https://doi.org/10.24926/jcotr.v25i1.2916)

Phelps, E., Zimmerman, S., Warren, A. E. A., Jeličić, H., von Eye, A., \& Lerner, R. M. (2009). The structure and developmental course of positive youth development (PYD) in early adolescence: Implications for theory and practice. Journal of Applied Developmental Psychology, 30(5), 571584. (https://doi.org/10.1016/j.appdev.2009.06.003)

Porter, S. R., \& Umbach, P. D. (2006). College major choice: An analysis of person-environment fit. Research in Higher Education, 474), 429-449. (https://doi.org/10.1007/s11162-005-9002-3)

Richelieu, A., \& Pons, F. (2011). How strong is my sports brand? The case of the Montréal Canadiens Hockey Club. Journal of Sponsorship, 4(4), 353-366.

Riedinger, K. (2015). Identity development of youth during participation at an informal science education camp. International Journal of Environmental and Science Education, 10(3), 453-475. (https://doi.org/10.12973/ijese.2015.254a)

Rosseel, Y. (2012). Lavaan: An R package for structural equation modeling. Journal of Statistical Software, 48(2). (https://doi.org/10.18637/jss.v048.i02)

Saeki, E., \& Quirk, M. (2015). Getting students engaged might not be enough: The importance of psychological needs satisfaction on social-emotional and behavioral functioning among early adolescents. Social Psychology of Education, 18(2), 355-371. (https://doi.org/10.1007/s11218014-9283-5)

Schmalz, D. L., Kerstetter, D. L., \& Kleiber, D. A. (2011). An evaluation of developmental outcomes at a free-choice oriented girls summer camp. Journal of Outdoor Recreation, Education, and Leadership, 3(1), 53-69. 
Shoffner, M. F., Newsome, D., Barrio Minton, C. A., \& Wachter Morris, C. A. (2015). A qualitative exploration of the STEM career-related outcome expectations of young adolescents. Journal of Career Development, 42(2), 102-116. (https://doi.org/10.1177/0894845314544033)

Smith, C., Akiva, T., Arrieux, D., \& Jones, M. M. (2006). Improving quality at the point of service. New Directions for Youth Development, 112, 93-108. (https://doi.org/10.1002/yd.195)

Su, Y., \& Reeve, J. (2010). A meta-analysis of the effectiveness of intervention programsesigned to support autonomy. Educational Psychology Review, 23(1), 159-188. (https://doi.org/10.1007/s10648-010-9142-7)

Tarbetsky, A. L., Martin, A. J., \& Collie, R. J. (2017). Social and emotional learning, social and emotional competence, and students' academic outcomes: The roles of psychological need satisfaction, adaptability, and buoyancy. In Social and emotional learning in Australia and the Asia-Pacific (pp. 17-37). Springer, Singapore.

Tiffany, J. S., Exner-Cortens, D., \& Eckenrode, J. (2012). A new measure for assessing youth program participation. Journal of Community Psychology, 40(3), 277-291. (https://doi.org/10.1002/jcop.20508)

Tovar, E. (2015). The role of faculty, counselors, and support programs on Latino/a community college students' success and intent to persist. Community College Review, 43(1), 46-71. (https://doi.org/10.1177/0091552114553788)

Trenshaw, K. F., Revelo, R. A., Earl, K. A., \& Herman, G. L. (2016). Using self-determination theory principles to promote engineering students' intrinsic motivation to learn. International Journal of Engineering Education, 32(3), 1194-1207.

Venezia, A., \& Jaeger, L. (2013). Transitions from high school to college. The Future of Children, 23(1), 117-136.

Walsh, D. W., Green, B. C., \& Cottingham, M. (2017). Exploring the efficacy of youth sport camps to build customer relationships. Leisure Studies, 36(5), 657-669. (https://doi.org/10.1080/02614367.2016.1240222)

Wang, M. T., \& Degol, J. L. (2017). Gender gap in science, technology, engineering, and mathematics (stem): Current knowledge, implications for practice, policy, and future directions. Educational Psychology Review, 29(1), 119-140. (https://doi.org/10.1007/s10648-015-9355-x)

Washburn, I. J., Acock, A., Vuchinich, S., Snyder, F., Li, K.-K., Ji, P., Day, J., DuBois, D., \& Flay, B. R. (2011). Effects of a social-emotional and character development program on the trajectory of behaviors associated with social-emotional and character development: Findings from three randomized trials. Prevention Science, 12(3), 314-323. (https://doi.org/10.1007/s11121-0110230-9) 
Journal of Youth Development | http://jyd.pitt.edu/ | Vol. 16 Issue 5 DOI 10.5195/jyd.2021.1083 Cultivating Youth Affinity for College

Wegemer, C. M., \& Eccles, J. S. (2019). Gendered STEM career choices: Altruistic values, beliefs, and identity. Journal of Vocational Behavior, 110(A), 28-42. (https://doi.org/10.1016/j.jvb.2018.10.020)

Weissberg, R. P., Durlak, J. A., Domitrovich, C. E., \& Gullotta, T. P. (Eds.). (2015). Social and emotional learning: Past, present, and future. In J. A. Durlak, C. E. Domitrovich, R. P. Weissberg, \& T. P. Gullotta (Eds.), Handbook of social and emotional learning: Research and practice (pp. 3-19). The Guilford Press.

Whittington, A. and Garst, B.A. (2018). The role of camp in shaping college readiness and building a pathway to the future for camp alumni. Journal of Youth Development, 13(1-2), 105-125. (https://doi.org/10.5195/jyd.2018.519)

Wilson, C., \& Sibthorp, J. (2018). Examining the role of summer camps in developing academic and workplace readiness. Journal of Youth Development, 13(1-2), 83-104.

(https://doi.org/10.5195/jyd.2018.563) 